\title{
Financial Development and Top Income Shares in OECD Countries
}

\author{
Anjan K. Saha ${ }^{1}$, Vinod Mishra ${ }^{2}$ and Russell Smyth ${ }^{3}$
}

\begin{abstract}
:
We use instrumental variable regression to isolate the causal impact of financial development on top income shares a panel of 14 OECD countries - five Anglo-Saxon countries, eight continental European countries and Japan - over a 110-year period. Our main finding is that financial development has a significant positive effect on top income shares, and that the most affluent are the biggest beneficiaries of financial development. In distribution terms, a onestandard-deviation increase in the private credit-GDP ratio corresponds to around a onestandard-deviation increase in the top $1 \%$ income share, with the top $1 \%$ income group deriving more benefits from financial development than the top 5\%, and the top 5\% deriving more benefit than the top $10 \%$. The effects are robust to various measures of top income shares and financial development and alternative estimation techniques, including nonparametric modelling. Financial development is typically viewed in positive terms in that it makes it easier to access credit and facilitates economic growth. Our results are important because they contribute to understanding of the potential negative effects of financial development.
\end{abstract}

Keywords: Financial development; top income shares.

JEL Codes: O15, O50, G00, E62

${ }^{1}$ La Trobe University, Melbourne, VIC 3086, Australia.

${ }^{2}$ Corresponding Author. Email: vinod.mishra@monash.edu, Phone: +61 399050038

${ }^{3}$ Monash University, Melbourne, VIC 3800, Australia.

(C) 2019 Anjan K. Saha, Vinod Mishra and Russell Smyth

All rights reserved. No part of this paper may be reproduced in any form, or stored in a retrieval system, without the prior written permission of the author.

monash.edu/ businesseconomics

ABN 12377614012 CRICOS Provider No. 00008C 


\section{Introduction}

The disparity between the top income holders and the rest of the population has received increasing attention. Empirical work on the topic has proliferated since century-long data on top income shares for many countries became available (see eg., Piketty, 2001;Atkinson 2004; Saez 2005; Moriguchi 2010; Atkinson et al. 2011; Veall 2012; Alvaredo et al. 2013; Saez 2017). Piketty's 2014 book Capital in the Twenty-First Century brought debate about income disparity to a wider audience. The primary concern in this debate is that the rich have been becoming richer over the last few decades. This widening income gap in societies poses questions, especially about the sources of the persistence of top income shares (TOP). However, one important potential cause of persistence in income disparities, about which we know very little, is the impact of financial development (FD) on top income shares.

Financial systems, in general, tend to channel more funds to the rich, who typically are more likely to have the required collateral or a history of previous loan repayments. The financial system also helps the rich to manage their portfolios efficiently and transform their financial assets to maximise their benefits. The rich, through their political and social connections, also influence the financial sector and its development in many ways that serve to benefit them. In particular, incumbent financiers may discourage potential new competitors from entering the financial sector (Rajan \& Zingales 2003). Such developments hinder competition and increase positional rents and profits flowing to incumbents.

One important channel via which FD affects TOP proposed by existing studies is imperfections in capital markets. In Galor and Zeira (1993), capital markets are imperfect because the interest rate for borrowers is higher than that for lenders due to enforcement costs. Education is then limited to individuals with sufficient initial wealth. Therefore, the offspring of the rich who receive a bequest from their parents have better access to investment in human capital and become skilled workers with high incomes. In contrast, people from low-income 
families inherit less and work as unskilled labourers, ending up with lower earnings. As a result, with a poorly developed financial sector, income inequality perpetuates over generations. Banerjee and Newman (1993) assume a similarly imperfect capital market in which the amount of borrowing is limited. This limitation disfavours the poor and forces them to choose occupations that mainly support wealthy employers, who have better access to funds, primarily due to their inherited wealth. Therefore, the initial wealth distribution determines occupational choices, which, in turn, widens the gap in the distribution of wealth. Both papers predict that reducing friction in the capital market can reduce the income gap in society.

Another important channel, via which FD influences TOP, is through economic growth. Financial development helps allocate capital efficiently and promote economic growth (King \& Levine 1993; Philippe et al. 1999; Piketty 2001; Beck \& Levine 2004; Jerzmanowski \& Nabar 2013; Piketty 2014; Arcand et al. 2015). Madsen and Ang (2016) posit FD as a robust source of economic growth through ideas, production, saving, investment and human capital accumulation channels. However, because the impact of growth on income distribution could be either positive or negative, the literature is inconclusive about how growth mediates the FD and TOP relationship. For instance, while Chambers (2007) and Lopez (2006) find growth to be a facilitator of unequal income distribution, Beck et al. (2007), Clarke et al. (2006) and Dollar et al. (2013) find the opposite. In Dollar and Kraay (2002), the shares of the lowest income quintiles increase as a function of economic development. On the other hand, the Kuznets (1955) curve suggests that there is an initial rise in income inequality in the early stages of economic development, but a diminishing trend in the mature stage.

We examine the effect of FD on TOP for a panel of 14 OECD countries - five AngloSaxon countries, eight continental European countries, and Japan - over a 110-year period. Focusing on the OECD economies has the advantage that it diminishes the unobserved 
heterogeneity that would arise from using a larger sample of countries over a short timedimension (Madsen et al., 2018). Another advantage of focusing on the OECD is that a large portion of the world's wealth is concentrated in the high-income OECD countries ${ }^{1}$ and that each of these countries are characterised by having highly sophisticated financial systems, which enable us to trace the effect of FD on TOP over a long period. The only existing study that touches on this issue is Roine et al. (2009), who include FD as one determinant of TOP in a broader study of the determinants of TOP in a sample of developed and developing countries. We differ from Roine et al. (2009) in that our focus is on the relationship between FD and TOP and that we give particular attention to addressing endogeneity of FD, which they do not. Another related paper is Tanndal and Waldenstrom (2018), who estimate the effect of 'Big Bang' financial market deregulation in Japan and the UK on top income shares in OECD countries since 1990. We differ from them in that our focus in on financial development, rather than financial deregulation and we look at a much longer time period.

Our choice of instruments was constrained by difficulties associated with finding instruments that vary over time and are available from 1900 for all 14 countries.

The first instrument that we use for FD is single-period lagged values of trade openness. Quy-Toan and Levchenko (2004) argue that trade openness is associated with faster FD in developed countries. Huang and Temple (2005) argue that trade openness triggers demand among firms for funds, as well as better financial management, which, in turn, increases the flow of funds from both domestic and foreign markets. Greenwood and Jovanovic (1990) argue that trade increases credit demand by reducing friction and information asymmetries. Once international trade expands, it creates new demand for funds for financing new projects and expanding old ones. While not all studies find that openness stimulates FD (see Stulz \&

\footnotetext{
1 According to the World Bank (2018) wealth per capita in the OECD is 52 times greater than in low-income countries.
} 
Williamson, 2003; Chinn \& Ito, 2006; De Bonis \& Stacchini, 2009), there is much empirical evidence that it does (eg. Baltagi et al. 2009). Because trade openness primarily creates demand for funds and better financial services, we use both de facto (trade volume as a fraction of GDP) and de jure (tariff rate) measures of openness as instruments for FD. A possible concern could be that trade openness or the tariff rate might influence top income shares directly or through the growth channel. Consistent with Alesina and Perotti (1996), we argue that once trade expands, the immediate impact is on the demand for credit or investment. This, in turn, affects growth and income distribution, but only in a later stage once investment is translated into productive economic activities. Equally, one might also be concerned that top income share may influence policymakers to change tariff rates. But using the one period-lagged tariff rate reduces the possibility of feedback running from top income shares and FD to the tariff rate or any other policy variable. Using the one-year lag for trade as our IV also reinforces our position that trade will not instantaneously change the distribution of income in the economy.

We use the agricultural sector's share in income as a second instrument for FD. Madsen and Ang (2016) use this variable as an instrument for FD when examining the extent to which FD transmits to economic growth for a sample of OECD countries over a similar time period. The intuition is based on the idea that agriculture-income holders in developed economies are less dependent on external finance than entrepreneurs and merchant groups (Madsen \& Ang 2016). While entrepreneurs, merchants and venture capitalists are always in need of funds and sophisticated financial services, the farming class cares little about this. Instead, agricultural interests oppose FD because it creates new employment demands in industries, which will place farm employment under pressure and ultimately increase agricultural wages. This hypothesis is consistent with Rajan and Zingales's (2003) model which suggests that conflict between business and non-business classes has persisted though the transformation from agriculture to industry. This idea is also in line with Acemoglu and Robinson (2000) who argue 
that the landed class always has an incentive to block industrialisation, which reduces the influence and political power of the landed class in favour of the entrepreneurial class.

With respect to the exclusion restriction, an important reason for thinking that the agricultural sector's share in income should only affect top income shares through the FD channel is that top income households derive their income mainly from sources other than agricultural sources. This is typically true, even in developing countries in which the agricultural share is relatively large. Even if top earners have any agricultural income, it is usually a negligible fraction of their total income. Hence, a change in agricultural share in GDP is not likely to directly affect the top income share. For the OECD, as a whole, empirical evidence on this point over the period we examine is scarce; however, there is some evidence for specific countries. Over the course of the twentieth century, Atkinson (2007) estimates that approximately two-thirds of UK top percentile group incomes stem from labor earnings from manufacturing, and the rest come from investment income and other sources. In the case of Japan, Moriguchi and Saez (2008) report that, over the same period, earnings from manufacturing comprise most of the income in the top percentile group.

We find that FD, as measured by the credit-GDP ratio, has a positive and significant impact on various top-income groups, including the top $0.1 \%, 1 \%, 5 \%$, and $2-10 \%$ of income shareholders. In our main results, we find that a one-percentage-point change in FD increases the top $1 \%$ of income shares by $0.7 \%$. In distribution terms, a one-standard-deviation increase in FD increases the top $1 \%$ of income shares by around one standard deviation. Our findings are robust to alternative approaches to defining FD and TOP and alternative techniques for addressing endogeneity, including alternative external instruments. We also present nonparametric estimates of the relationship between FD and TOP in which we show that the relationship between FD and TOP was positive for most of the twentieth century. 
Financial development is often lauded for increasing access to credit, lifting the poor out of poverty and contributing to economic growth. However, little attention has been given to the potential negative effects of financial development. A few recent studies for much shorter periods than we consider have found that FD increases income inequality (see eg. de Haan \& Sturm, 2017), but most studies have found that FD is associated with lower inequality. Given our finding that financial development increases top income shares, our results contribute to our understanding of the negative effects of the financial system ("the dark side of finance").

\section{Empirical specification}

We start with, the following simple model that relates FD to TOP:

$$
T O P_{i t}=\kappa+\beta F D_{i t}+\gamma^{\prime} * C V_{i t}+h_{i}+u_{i t}
$$

where $i$ refers to countries, $t$ to time, $h_{i}$ to country-specific fixed effects, $C V$ to a vector of exogenous control variables and $u_{i t}$ to the error term. The dependent variable, TOP represents the top income shares, and $F D_{i t}$ represents financial development. The coefficients are denoted by $\kappa, \beta$ and $\gamma$, of which $\beta$ is the coefficient of primary interest.

Ordinary least square (OLS) estimates may be biased due to potential omission of some variables and errors in measurement. They may also be biased if FD is endogenous. For instance, $F D_{i t}$ may be correlated with the error term or with $h_{i}$-country-specific fixed effects.

We, therefore, first measure the predicted value of $F D_{i t}$ using the following equation to capture exogenous variations in $F D_{i t}$ that can exploit the variations in $T O P_{i t}$ in Eq. (1).

$$
F D_{i t}=\pi+\theta I V_{i t}+\phi^{\prime} * C V_{i t}+g_{i}+e_{i t}
$$

Here, $I V_{i t}$ refers to instruments for financial development, $g_{i}$ to country-specific fixed effects and $e_{i t}$ to the error term. $\pi, \theta$ and $\phi$ denote the coefficients.

We use lagged values for the tariff rate and trade volume as the fraction of GDP as proxies for trade openness to instrument for FD. We also use the agricultural sector's share in 
income as an instrument for FD based on the idea that agriculture-income holders in developed economies are less dependent on external finance than entrepreneurs and merchant groups. Rajan and Zingales (2003) argue that FD, in general, reduces the influence of the rich on new entrants into the market. This tends to lowers the possibility of reverse causality from TOP to FD. However, we do not rule out the possibility of a feedback effect from TOP to FD or trade openness (see Kumhoff et al, 2015; Bordo \& Meissner, 2012 for the potential reverse causal relationship). The rich may block new entrants from participating in the market. Industry lobbies, who usually belong to the top income groups, may also influence the government to reduce tariff rates. The relationship between each of the external instruments and FD is shown in Figure 1. They seem to suggest a linear relationship between each of the instruments and FD. We also perform a Granger causality test for the panel (using the approach suggested in Dumitrescu and Hurlin (2012)) to determine whether each of the instruments Granger-causes FD. In each case, the null hypothesis that each of our instruments does not Granger-cause FD is rejected at the $1 \%$ level of significance $(\mathrm{p}=0.000$, in each case).

We address omitted variable bias using control variables $\left(C V_{i t}\right)$ that are related to both FD and top income shares and are standard in the literature. They are physical and human capital, investment, R\&D expenditure, savings, government expenditure and top marginal tax rates. Saving, investment and research expenditure may have a bias toward the rich because the rich can easily derive benefits from larger investments including investments in high-tech research. Government expenditure also can be pro-rich if it is not sufficiently directed to the poor through policy intervention. In our model, we, therefore, control for these variables.

We employ a range of techniques to check the robustness of the causal relationship between FD and TOP. We extend our basic model to introduce dynamicity and measure it with internal instruments in difference- and system- General Method of Moments (GMM) settings. We extend our model further to investigate the extent of deviation of the relationship in the 
short-term from the long term by using error correction models allowing for heterogeneous slopes and intercepts across countries. Finally, we address the potential for structural breaks over a long period to introduce non-linearities into the relationship between FD and TOP and present nonparametric estimates as a robustness check on our point estimates.

\section{Data, variables and measures}

We use panel data from 14 OECD countries over the period from 1900 to $2009 .^{2}$ All the variables were transformed into natural logarithms for ease of interpretation. We average the data over five years to smooth out short-run business cycle fluctuations. Because not all the variables have observations for every year, taking five-year averages also mitigates the problem of missing data. The non-overlapping five-year-period average over the full sample period also enables long-term inferences. Variable descriptions and data sources are given in Table 1. Appendix Tables A1 and A2 provide summary statistics for the key variables.

\subsection{Measures of top income shares and financial development}

Top income shares are measured using the before-tax incomes of top income groups as a percentage of GDP. We use the top $1 \%$ income share in benchmark regressions and the top $10 \%, 5 \%, 0.5 \%, 0.1 \%$, and $2-10 \%$ in robustness checks. The data are from the World Wealth and Income Database (WID) of the Paris School of Economics. They provide a comparable series of top income shares across countries, although potential problems regarding different income definitions, income tax units, and changes in legislation at different points in time across countries cannot be completely avoided (see Atkinson (2005), for details). However, we mitigate this problem by focusing on 14 OECD countries, all of which are high-income countries and all of which engage in large amounts of trade with each another.

\footnotetext{
${ }^{2}$ Our sample ends in 2009 because after that year, top $1 \%$ data is not available for Canada, Denmark, Finland or Japan and only one observation is available for Norway. Other top income shares such as top $0.1 \%, 0.5 \%, 5 \%$ and $10 \%$, that we employ as robustness checks, are also not available for all 14 countries from 2010.
} 
Financial development is measured by credit to the private sector as a percentage of GDP, which is standard in the literature (Beck et al. 2007). We employ century-long private credit data taken from Madsen and Ang (2016). The Global Financial Development Database (GFDD) of the World Bank also provides data on private credit, but the data started only in $1960 .^{3}$ As alternative measures of FD, we also use total bank assets (as a percentage of GDP) and the broad money supply. These data come from Madsen and Ang (2016).

\subsection{Other variables}

Financial development, in general, promotes economic development (ED), and vice versa, and economic development may influence top income shares. ${ }^{4}$ We, therefore, control for the initial level of GDP per capita in all the regressions as a measure of economic development. It is measured as the earlier period's income, i.e., the average of the previous window of five years. Initial GDP per capita also functions as a proxy for many latent economic and societal variables that are not measurable. The data are in real GDP per capita (in 1990 International Geary-Khamis dollars) and come from the Maddison Project Database.

Changes in tax policies can have a significant impact on top income shares. The top marginal tax rate is a useful policy tool to downsize top income shares. For example, by implementing higher statutory marginal tax rates, Denmark reduced its top $1 \%$ of income shares from a maximum of 28\% in 1917 to about 6\% in 2010 (Atkinson \& Søgaard 2013). Atkinson and Leigh (2013) find an increase in top income shares due to a decrease in the top marginal tax rates on wage income. However, they find a decrease in top income shares when the top marginal tax rates on investment income increase. Progressive taxation is also one of

\footnotetext{
${ }^{3}$ The correlation between Madsen and Ang's (2016) private credit data with the GFDD data is 0.97.

${ }^{4}$ Andrews et al. (2011), for example, using data from 12 OECD countries, find a positive effect on the part of top income shares on economic growth from the 1950s onward. This finding does not support any systematic impact on the part of the top income shares on economic growth in the entire twentieth century.
} 
the tools advocated by Piketty (2014) to minimise the income gap between the rich and the poor. Thus, we control for top marginal tax rates that are statutory top tax rates. The top marginal tax rates are taken from Roine et al. (2009), except for Denmark. The Denmark data come from Atkinson and Søgaard (2013).

Research and development (R\&D) may have a substantial impact on top income shares. The adoption of new research and technologies predominantly increases the demand for highskilled workers, which may exacerbate the wage gap by providing a high level of skill-based remuneration (Jerzmanowski \& Nabar 2013). Technological development, specifically information and communication technology, has been continuously reshaping the financial sector and also changing the distribution of income in societies. Madsen and Ang (2016) provide evidence that $\mathrm{R} \& \mathrm{D}$ has contributed to channelling FD into economic growth. Ilyina and Samaniego (2011) show that well-functioning financial markets direct resources towards industries, in which growth is driven by $\mathrm{R} \& \mathrm{D}$. We use data on research and development expenditure as a percentage of the GDP from Madsen and Ang (2016). The data for saving, investment and education also come from Madsen and Ang (2016). Saving, investment and education may affect both FD and top income shares simultaneously because they can affect both top income shares and FD through economic growth and other channels.

\section{Results}

\subsection{Effect of financial development on the top $1 \%$ of income shares}

Panel A of Table 2 reports the OLS and two-stage least-squares regression results for the relationship between FD and the top $1 \%$ of income shares. In column (1), when we regress the top $1 \%$ of income shares on private credit only, private credit is insignificant. In column (2), we include a single-period lag of GDP per capita as a control. The introduction of the first lag of GDP per capita as an explanatory variable increases the $\mathrm{R}^{2}$ value substantially (from 0.002 to 0.477 ), and the coefficient on private credit becomes significant. A one percent 
increase in FD, measured by the private credit-GDP ratio, is associated with a 0.19 percent increase in the top $1 \%$ of income share. In Columns (3) to (5), we use instrumental-variables to capture the role of variations in FD in explaining variations in the top income shares.

Based on the basic model, as depicted by Equation (1), Column (3) in panel A reports the impact of FD on the top $1 \%$ of income shares, using the one-year lags of trade volume as a fraction of GDP and the tariff rate as instruments for FD. The combination of these two instruments confers the advantage of identifying the model through over-identification tests. In Column (3), the magnitude of the coefficient increased more than three-fold. The $\mathrm{R}^{2}$ value also increased substantially. The result supports the notion that the use of the instrument reduces simultaneity bias. The second-stage results are based on the predicted value of FD measured in the first stage, based on Equation (2), as reported in the same column of Panel B. In all the regressions in Table 2, we only account for the initial GDP per capita as a control variable because it captures overall economic conditions in countries. We use both de facto and de jure measures of the trade openness lags of the previous period in predicting FD in Column (3), based on the notion that a new tariff rate takes some time to have an impact on FD. The results show that increased trade volume and reduced tariff rates are associated with improved FD, as measured by private credit. Initial GDP per capita also affects FD, confirming the positive relationship between economic and financial development.

In Column (4), we use a single-period lagged value of trade volume and the agricultural share of GDP as instruments for private credit. The results also suggest that FD has a significant positive impact on top income shares. In Column (5), we combine all three instruments. The coefficient of private credit is very similar to that in Column (4).

The first-stage partial $\mathrm{R}^{2}$ values (0.17 to 0.20$)$ and the Hansen J statistic across Columns (3) to (5), provide strong support for the basic bivariate model. Moreover, each of the firststage F-statistics in Panel B is significantly higher than the rule-of-thumb of 10 proposed by 
Staiger and Stock (1997), providing confidence that the instruments are strong and valid. We consider the bivariate model in Column (5) as our benchmark model for the subsequent analysis. In Column (5), a one-percentage-point change in FD increases the top $1 \%$ of income shares by $0.7 \%$. In distribution terms, a one-standard-deviation increase in FD, as measured by the credit-GDP ratio, increases the top $1 \%$ of income shares by around one standard deviation.

\subsection{Full model}

In Table 3, in addition to initial GDP, we account for variables that may have an influence on both financial development and top income shares and are standard in the literature. We control for investment, saving and human capital because they are the primary variables that affect production in a standard Cobb-Douglas function. We also control for government expenditure and R\&D expenditure because they may influence both of our main variables of interest. Column (1) provides the OLS results for the model with a full set of control variables. The association between private credit and the top $1 \%$ of income shares is very similar to that in the basic model in Column (2) of Table 2. Column (2) in Table 3 adds the top marginal tax rates as an additional control variable. The top marginal tax has a substantial negative impact on the top $1 \%$ of income shares. The coefficient on FD does not change very much, although the number of observations are reduced drastically from 186 to 134 , given that data on the top marginal tax rate is not available for all countries.

In Columns (3) and (4), we report the instrumental variable regressions of the full model without and with top the marginal tax rates, respectively. Again, the coefficients on private credit in Columns (3) and (4) are very similar to the corresponding coefficients in Columns (4) and (5) of our basic model. Across all four columns, R\&D intensity has a positive impact on the top $1 \%$ of income shares, irrespective of the model used. This provides strong support for the notion that expenditure on R\&D significantly benefits the rich. On the other hand, government expenditure seems to be pro-poor or at least not pro-rich. Economic development helps economies to reduce inequality. In the instrumental-variable regressions in Columns (3) 
and (4), we find that investment and saving do not have a significant impact on top income shares. A tertiary level of education, however, seems to provide incentives to the rich. The implication is that the rich derive a benefit from higher education because they are the primary owners of new technologies that require a highly educated workforce.

\subsection{Exclusion restriction analysis}

The exclusion restriction implied by our instrumental-variable strategy requires that the instrumental variables have no direct impact on top income shares, other than through their effect on FD. To test the validity of this requirement, we use simple exclusion restriction tests that are popular in the recent literature (for instance, see the similar strategy undertaken by Acemoglu et al. (2001) and Madsen and Ang (2016), among others). The main idea is that a valid instrument will work only through the FD variable and it would not have any direct effect on the dependent variable. Hence, controlling for any of the instruments in the second stage should result in the instrument having an insignificant impact on the top income measure.

In Table 4, Column (1), we report the results after controlling for trade volume as a fraction of GDP in the second stage, while the two other instruments are used as the excluded instruments. Trade volume as a fraction of GDP has no significant effect on top income shares in the second stage. In Column (2), we repeat the estimation of the full model but include the top marginal tax rate. In Column (3), the same procedure has been followed as in Column (1), but in this case, in the second stage, the tariff rate is used as an additional control variable, using the two other instruments as the excluded instruments. Similar to Column (1), using the tariff rate as an additional control variable does not have any significant impact on the top income measure. In Column (4), we repeat the estimation of the full model, but again include the top marginal tax rate. The coefficient on the control variables in each of the regressions are also insignificant, which supports the validity of our external instruments.

\subsection{Results using alternative measures of top income shares and financial development}


We first perform robustness checks with alternative proxies for top income shares. The first five columns of Table 5 show the estimates of the effect of private credit on various proxies for top income shares (top $10 \%, 5 \%, 0.5 \%, 0.1 \%$, and $2-10 \%$ of income shares). In each column, panel A provides the results for the basic bivariate model, which includes only initial GDP per capita as a control variable; panel B provides the full model, excluding the top marginal tax rate, and in panel $\mathrm{C}$, we account for the marginal tax rate as a control, in addition to all the other control variables. We note that irrespective of the number of control variables, the impact of FD on top income shares remains mostly the same across the panels.

Next, we perform robustness tests using alternative proxies for FD. Columns (6) and (7) show the results using bank assets and broad money as alternative measures of FD. The results are robust to use of both measures. Irrespective of the measures used, FD has a highly significant and positive impact on the top income shares across all panels.

Another interesting finding is that the impact of FD on top income shares is larger in the higher-earning top income groups (Columns (1) to (4)). This implies that among the rich, more affluent groups are deriving more benefits from greater FD. The contribution of FD to the top $2-10 \%$ of income shares in Column (5) is comparatively smaller, which reinforces that FD has a more significant effect on the very rich.

In summary, all of the results suggest that FD has a positive and highly significant impact on top income shares, irrespective of how we neasure FD or top income share. The diagnostic test results in the first and second stages also support this conclusion.

\subsection{Robustness check with LSDVC and GMM estimates}

Table 6 presents results with corrected least square dummy variable (LSDVC) and (GMM), controlling for initial GDP per capita in Panel A and GDP per capita, as well as top marginal tax rates, in Panel B. Columns (1a), (1b) and (1c) report estimates using the LSDVC technique, initiated via the $\mathrm{AH}, \mathrm{AB}$ and $\mathrm{BB}$ estimators, respectively. The LSDVC technique is efficient with a narrow, unbalanced panel with long time series, as in our case. The coefficient 
on FD is significant at the $1 \%$ level. However, the estimates are very low in comparison with the instrumental variable regressions. This may be due to the inclusion of a lagged dependent variable to capture the dynamicity of the model.

System and difference GMM techniques have the advantage of addressing the feedback effect on the part of the dependent variable on the explanatory variables using internal instruments. The results are in Columns (2a) and (2b). The coefficient on private credit is positive and significant at the $1 \%$ level. The size of this coefficient is much larger than the LSDVC estimates and is similar in magnitude to the OLS results.

The above discussions are based on Panel A, in which we only control for GDP per capita. Irrespective of the methods applied, we find that financial development has a significant positive impact on the top $1 \%$ of income shares. In Panel B, the top marginal tax rate is included as an additional control variable to examine the impact of the top marginal tax rate in dynamic models. The results show that our coefficient of interest remains positive and significant and is slightly lower than the coefficient obtained in Panel A. The impact of the top marginal tax rate on top income shares is always negative, as expected; however, in the presence of the financial development variable, the impact of tax policy is not always significant.

\subsection{Robustness check using error-correction models}

The LSDVC estimator requires the explanatory variables to be strictly exogenous. We, therefore, estimate the financial development and top income relationship with other dynamic models to compare the results. Table 7 reports the results of the mean group estimations (MG), pooled mean group estimation (PMG) and dynamic fixed-effect estimation (DFE) through error correction in the long term. All the variables included in the regressions are $I(1)$. The results in Table 6 confirm a long-term relationship between private credit and the top $1 \%$ of income shares. The adjustment terms $\left(\emptyset_{i}\right)$ that characterise the error-correction speed are significant at the $1 \%$ level across the estimators with an expected negative sign. Across the estimates, private 
credit has a positive impact, and GDP per capita has a negative impact on the top $1 \%$ of income shares. However, the impacts are highly significant only in the PMG and DFE estimates. The Hausman test between the groups suggests that DFE is the most efficient estimator of the three.

The DFE results show that a $1 \%$ increase in private credit is associated with an increase in the top $1 \%$ of income shares of $0.75 \%$, which is very close to our benchmark result $(0.7 \%)$ in Table 2. The DFE estimates, thus, reconfirm the contribution of financial development to enhancing the top income shares in our benchmark results in Table 2.

\subsection{Non parametric estimates}

Given that the data spans a period of nearly 110 years, one may be concerned that the point estimates obtained from OLS and IV regressions are not capable of fully capturing the nature of the relationship between financial development and the top income shares in our sample. In order to address this limitation associated with point estimates, and to fully capture the complex nature of the relationship between the financial development and the top income shares, we use a non-parametric model to further study this relationship. The non-parametric model can be specified as follows (Silvapulle at al., 2017; Hailemariam at al., 2018):

$$
\begin{aligned}
\ln \left(T O P_{i t}\right)= & f_{i}(t)+\beta_{1}(\mathrm{t}) \ln \left(F D_{i t}\right)+\beta_{2}(\mathrm{t}) \ln \left(G D P_{i t}\right)+\beta_{3}(\mathrm{t}) \ln \left(\operatorname{Inv}_{i t}\right)+\beta_{4}(\mathrm{t}) \ln \left(\operatorname{Sav}_{i t}\right) \\
& +\beta_{5}(t) \ln \left(R D I_{i t}\right)+\beta_{6}(t) \ln \left(E D U_{i t}\right)+\beta_{7}(t) \ln \left(T e r t_{i t}\right)+\beta_{8}(\mathrm{t}) \ln \left(G E_{i t}\right) \\
& +u_{i t}
\end{aligned}
$$

In the above equation $f_{i}(t)=f_{i}\left(\frac{t}{T}\right)$, for $i=1,2, \ldots, N$ are individual trend functions

for each country in the sample, $\beta_{i}(t)=\beta_{i}\left(\frac{t}{T}\right)$ are the time-varying coefficients. $F D_{i t}$ represents financial development as measured by private credit as a percentage of GDP, $G D P_{i t}$ is initial GDP per capita, $I n v_{i t}$ is Investment, $S a v_{i t}$ is Savings, $R D I_{i t}$ is R\&D intensity, $E D U_{i t}$ and Tert $_{i t}$ are average years of education and the percentage of population with tertiary educational qualifications respectively and $G E_{i t}$ is government expenditure.

This specification can be estimated using local linear dummy variable estimation (LLDVE), following an approach similar to Silvapulle at al. (2017) and Hailemariam at al 
(2018). We use the leave-one-unit-out least square validation method outlined in Silvapulle at al. (2017) to select the bandwidth for LLDVE and employ a wild bootstrap procedure to compute the time confidence intervals for the common trend and coefficient functions. The LLDVE results are presented in Figure 2. The findings suggest that the relationship between private credit and top income share is indeed non-linear. But, apart from a period in the 1920s and 1930s, around the Great Depression, in which the relationship is insignificant, private credit is positive throughout the twentieth century. Thus, the non-parametric estimates in Figure 2 are consistent with our parametric point estimates presented in Table 2.

\section{Conclusions}

Although top incomes have received increased attention in the last few years, we know very little about the effect of FD on top income shares. Our study has been the first to focus on the relationship between FD and top incomes by using an instrumental variable approach to exploit the causal impact of FD on top income shares. We find that irrespective of the measures used for financial development and top income shares, financial development increases top income shares. Specifically, we have found that a one-standard-deviation increase in private credit (as a percentage of GDP) is associated with around a one-standard-deviation increase in the top $1 \%$ of income shares. We also found that the most affluent are the biggest beneficiaries of financial development.; in particular the top $1 \%$ income group derives more benefits from financial development than the top 5\%, and the top 5\% derives more benefit than the top $10 \%$.

Another significant finding of our work is that the shares of the top income groups remain partly balanced because the impact of financial and economic development affect top income shares in opposite directions. While financial development contributes to increasing top income shares, economic development reduces them. Thus, economic development (increasing income per capita) remains crucial for OECD countries in that it can dampen the aggressive and positive impact of financial development on top income shares. Interestingly, we do not find that top marginal tax rates have any significant effect on top income shares. In 
contrast, rising tertiary education and R\&D expenditures boost the incomes of the rich. The results substantiate Piketty's (2014) worries regarding the increasing gap between the rich and the poor because advances in both technology and higher education ultimately favour the rich, allowing them to consolidate their wealth, given that they are the primary beneficiaries of capital returns and are the leading employers of the highly educated workforce. 


\section{References}

Acemoglu, D., Robinson, J.A., 2000. Political Losers as a Barrier to Economic Development. The American Economic Review 90, 126-130

Acemoglu, D., Johnson, S., Robinson, J.A., 2001. The Colonial Origins of Comparative Development: An Empirical Investigation. American Economic Review 91, 1369-1401

Alesina, A., and Roberto Perotti. 1996. Income distribution, political instability, and investment. European Economic Review 40(6): 1203-1228.

Alvaredo, F., Atkinson, A.B., Piketty, T., Saez, E., 2013. The Top 1 Percent in International and Historical Perspective. Journal of Economic Perspectives 27, 3-20

Andrews, D., Jencks, C., \& Leigh, A. (2011). Do Rising Top Incomes Lift All Boats ? The B . E . Journal of Economic Analysis \& Policy, 11(1).

Arcand, J.L., Berkes, E., Panizza, U., 2015. Too much finance? Journal of Economic Growth 20, 105148

Atkinson, A.B., 2004. Income tax and top incomes over the twentieth century. Revista de Economia Publica 168, 123-141

Atkinson, A.B., 2005. Comparing the Distribution of Top Incomes across Countries. Journal of the European Economic Association 3, 393-401

Atkinson, A.B., Leigh, A., 2013. The Distribution of Top Incomes in Five Anglo-Saxon Countries Over the Long Run. Economic Record 89, 31-47

Atkinson, A.B., Piketty, T., Saez, E., 2011. Top Incomes in the Long Run of History. Journal of Economic Literature 49, 3-71

Atkinson, A.B., Søgaard, J.E., 2013. The long-run history of income inequality in Denmark: Top incomes from 1870 to 2010. In: EPRU Working Paper Series, 2013-0.

Baltagi, B.H., P.O. Demetriades and S.H. Law (2009). Financial Development and Openness: Evidence from Panel Data. Journal of Development Economics, 89(2), 285-296

Banerjee, A.V., Newman, A.F., 1993. Occupational Choice and the Process of Development. Journal of Political Economy 101, 274-298

Beck, T., Demirgüç-Kunt, A., Levine, R., 2007. Finance, inequality and the poor. Journal of Economic Growth 12, 27-49

Beck, T., Levine, R., 2004. Stock markets, banks, and growth: Panel evidence. Journal of Banking \& Finance 28, 423-442.

Bordo, M.D., Meissner, C.M. (2012). Does inequality lead to a financial crisis? Journal of International Money and Finance, 31, 2147-2161.

Bruno, G.S.F., 2005. Estimation and inference in dynamic unbalanced panel-data models with a small number of individuals. The Stata Journal 5, 473-500

Chambers, D., 2007. Trading places: Does past growth impact inequality? Journal of Development Economics 82, 257-266. 
Chinn, M.D. and H. Ito (2006). What Matters for Financial Development? Capital Controls, Institutions, and Interactions. Journal of Development Economics, 81 (1), 163-192.

Clarke, G.R.G., Lixin Colin, X., Heng-Fu, Z., 2006. Finance and Income Inequality: What Do the Data Tell Us? Southern Economic Journal 72, 578-596

De Bonis R. and M. Stacchini (2009) What Determines the Size of Bank Loans in Industrialized Countries? The Role of Government Debt. Bank of Italy Working Paper 707, Banca d'Italia, Rome.

de Haan, J. and J-E. Sturm (2017). Finance and Income Inequality: A Review and New Evidence. European Journal of Political Economy, 50, 171- 195.

Dollar, D., Kleineberg, T., Kraay, A., 2013. Growth still is good for the poor. URL http://elibrary.worldbank.org/doi/pdf/10.1596/1813-9450-6568

Dollar, D., Kraay, A., 2002. Growth Is Good for the Poor. Journal of Economic Growth 7, 195-225

Dumitrescu, E.-I., Hurlin, C., 2012. Testing for Granger non-causality in heterogeneous panels. Economic Modelling 29, 1450-1460

Galor, O., Zeira, J., 1993. Income Distribution and Macroeconomics. Review of Economic Studies 60, $35-52$.

Greenwood, J., Jovanovic, B., 1990. Financial Development, Growth, and the Distribution of Income. Journal of Political Economy 98, 1076-1107.

Hailemariam, A., Smyth, R. \& Zhang, X. (2018). Oil prices and economic policy umncertainty: Evidence from a nonparametric panel data model. Unpublished manuscript, Department of Economics, Monash University.

Huang, Y., Temple, J., 2005. Does external trade promote financial development? Federal Reserve Bank of St Louis, St. Louis

Ilyina, A., Samaniego, R., 2011. Technology and Financial Development. Journal of Money, Credit and Banking 43, 899-921

Jerzmanowski, M., Nabar, M., 2013. Financial development and wage inequality: Theory and evidence. Economic Inquiry 51, 211-234

King, R.G., Levine, R., 1993. Finance and growth: Schumpeter might be right. Quarterly Journal of Economics 108, 717.

Kumhof, M., Rancière, R., Winant, P. (2015). Inequality, leverage and crises. American Economic Review, 105, 1217-1245

Kuznets, S., 1955. Economic growth and income inequality. American Economic Review 45, 1

Lopez, H., 2006. Growth and inequality: Are the 1990s different? Economics Letters 93, 18-25

Madsen, J. B. 2010. The anatomy of growth in the OECD since 1870. Journal of Monetary Economics, 57(6), 753-767. 
Madsen, J. B. 2014. Human capital and the world technology frontier. Review of Economics and Statistics, 96(4), 676-692.

Madsen, J.B., Ang, J.B., 2016. Finance-Led Growth in the OECD since the Nineteenth Century: How Does Financial Development Transmit to Growth? Review of Economics and Statistics 98, $552-572$

Madsen, J.B., Islam, M. R., \& Doucouliagos, H. (2018). Inequality, financial development and economic growth in the OECD, 1870-2011. European Economic Review, 101.

Moriguchi, C., 2010. Top wage incomes in Japan, 1951-2005. Journal of the Japanese and International Economies 24, 301-333.

Philippe, A., Eve, C., Cecilia, G.-P., 1999. Inequality and economic growth: The perspective of the new growth theories. Journal of Economic Literature 37, 1615-1660

Piketty, T., 2001. Income inequality in France, 1900-1998. In: CEPR Discussion Papers, No. 2876

Piketty, T., 2014. Capital in the Twenty-First Century. Harvard University Press.

Quy-Toan, D., Levchenko, A.A., 2004. Trade and financial development. In: Policy Research Working Paper. World Bank, Washington DC

Rajan, R.G., Zingales, L., 2003. The great reversals: the politics of financial development in the twentieth century. Journal of Financial Economics 69, 5-50

Roine, J., Vlachos, J., Waldenström, D., 2009. The long-run determinants of inequality: What can we learn from top income data? Journal of Public Economics 93, 974-988

Saez, E., 2005. Top Incomes in the United States and Canada Over the Twentieth Century. Journal of the European Economic Association 3, 402-411

Saez, E., 2017. Income and Wealth inequality. Evidence and Policy Implications. Contemporary Economic Policy 35, 7-25.

Silvapulle, P., Smyth, R., Zhang, X. \& Fenech, J.P. (2017). Nonparametric panel data model for crude oil and stock market prices in net oil importing countries. Energy Economics 67, 255-267

Staiger, D., Stock, J.H., 1997. Instrumental Variables Regression with Weak Instruments. Econometrica $65,557-586$.

Stulz, R. and R. Williamson (2003). Culture, Openness, and Finance. Journal of Financial Economics, 70, 313-349

Tanndal, J., \& Waldenström, D. (2018). Does Financial Deregulation Boost Top Incomes? Evidence from the Big Bang. Economica, 85(338), 232-265.

Veall, M.R., 2012. Top income shares in Canada: recent trends and policy implications. Portion des plus hauts revenus au Canada: tendances récentes et implications pour les politiques . Canadian Journal of Economics 45, 1247-1272.

World Bank (2018). The Changing Wealth of Nations 2018: Building a Sustainable Future (World Bank: Washington DC). 


\section{Tables and Figures}

Table 1 Description of variables and data sources

\begin{tabular}{|c|c|c|}
\hline Variable & Description & Source \\
\hline $\begin{array}{l}\text { Top income } \\
\text { shares }\end{array}$ & $\begin{array}{l}\text { Data are downloaded from World Top Income Database } \\
\text { of Paris School of Economics. They are before tax data } \\
\text { and are expressed as a percentage of GDP. The data are } \\
\text { derived from the tax returns of the countries. }\end{array}$ & $\begin{array}{l}\text { World Wealth and } \\
\text { Income Database } \\
\text { (wid.world) }\end{array}$ \\
\hline Private credit & Credit to private sector as percentage of GDP & $\begin{array}{l}\text { Madsen and Ang } \\
\text { (2016) }\end{array}$ \\
\hline Bank assets & Bank assets as a percentage of GDP & $\begin{array}{l}\text { Madsen and Ang } \\
\text { (2016) }\end{array}$ \\
\hline Broad Money & $\begin{array}{l}\text { Broad money includes currency, other liquid assets as } \\
\text { well as long-term investment in bonds and other liquid } \\
\text { assets }\end{array}$ & $\begin{array}{l}\text { Madsen and Ang } \\
\text { (2016) }\end{array}$ \\
\hline GDP per capita & $\begin{array}{l}\text { GDP per capita is measured in } 1990 \text { International } \\
\text { Geary-Khamis dollars from the Maddison Project } \\
\text { Database. }\end{array}$ & http://www.ggdc.net \\
\hline $\begin{array}{l}\text { Trade } \\
\text { openness }\end{array}$ & Imports as the percentage of $\mathrm{GDP}^{5}$ & $\begin{array}{l}\text { Madsen and Ang } \\
\text { (2016) }\end{array}$ \\
\hline Tariff rate & $\begin{array}{l}\text { Nominal import duties as a percentage of nominal } \\
\text { import values of goods }\end{array}$ & Madsen (2010) \\
\hline $\begin{array}{l}\text { Agriculture } \\
\text { share }\end{array}$ & $\begin{array}{l}\text { Agriculture share in income as the share of agricultural } \\
\text { production in total GDP }\end{array}$ & $\begin{array}{l}\text { Madsen and Ang } \\
\text { (2016) }\end{array}$ \\
\hline $\begin{array}{l}\text { Educational } \\
\text { attainment }\end{array}$ & Educational attainment in average years of education & Madsen (2014) \\
\hline $\begin{array}{l}\text { Tertiary } \\
\text { education }\end{array}$ & $\begin{array}{l}\text { Fraction of the population in the } 18 \text { - to } 22 \text {-year-age } \\
\text { cohort enrolled in tertiary education }\end{array}$ & $\begin{array}{l}\text { Madsen and Ang } \\
\text { (2016) }\end{array}$ \\
\hline Investment & Investment as a percentage of total capital stock & $\begin{array}{l}\text { Madsen and Ang } \\
\text { (2016) }\end{array}$ \\
\hline $\begin{array}{l}\text { Government } \\
\text { expenditure }\end{array}$ & Government expenditure as a percentage of GDP & Roine et al. (2009) \\
\hline $\begin{array}{l}\text { Top marginal } \\
\text { tax rates }\end{array}$ & $\begin{array}{l}\text { These are statutory top tax rates of a country. For UK } \\
\text { and USA, we use the tax rates applicable to incomes } \\
\text { higher than five times GDP per capita, following Roine } \\
\text { et al. (2009) }\end{array}$ & Roine et al. (2009) \\
\hline R\&D intensity & Research and development expenditure as $\%$ of GDP. & $\begin{array}{l}\text { Madsen and Ang } \\
\text { (2016) }\end{array}$ \\
\hline
\end{tabular}

Note: All the variables are expressed in natural logarithm. Professor Jakob Madsen shared the tariff data.

\footnotetext{
${ }^{5}$ Export data is not available for many countries in the early decades of the last century. Hence, ImportGDP ratio is used as a proxy for openness.
} 
Table 2 Effect of Financial development on top 1\% income shares

\begin{tabular}{|c|c|c|c|c|c|}
\hline $\begin{array}{l}\text { Dep. Var.= Top } 1 \% \\
\text { income shares }(\ln )\end{array}$ & $\begin{array}{l}(1) \\
\text { OLS }\end{array}$ & $\begin{array}{c}(2) \\
\text { OLS }\end{array}$ & $\begin{array}{c}(3) \\
\text { IV1+IV2 }\end{array}$ & $\begin{array}{c}(4) \\
\text { IV1+IV3 }\end{array}$ & $\begin{array}{c}(5) \\
\text { IV1+IV2+IV3 }\end{array}$ \\
\hline & \multicolumn{5}{|c|}{ Panel A: 2SLS results } \\
\hline $\begin{array}{l}\text { Private credit } \\
\text { [Beta coefficient] }\end{array}$ & $\begin{array}{l}-0.029 \\
{[-0.05]} \\
(0.036)\end{array}$ & $\begin{array}{c}0.187 * * * \\
{[0.30]^{* * *}} \\
(0.029)\end{array}$ & $\begin{array}{c}0.629 * * * \\
{[1.1]^{* * *}} \\
(0.089)\end{array}$ & $\begin{array}{c}0.701 * * * \\
{[1.2]^{* * *}} \\
(0.096)\end{array}$ & $\begin{array}{c}0.633 * * * \\
{[1.1]^{* * *}} \\
(0.088)\end{array}$ \\
\hline $\begin{array}{l}\text { Initial GDP per capita } \\
\text { [Beta coefficient] }\end{array}$ & & $\begin{array}{c}-0.448 * * * \\
{[-0.78]^{* * *}} \\
(0.029)\end{array}$ & $\begin{array}{c}-0.714 * * * \\
{[-1.25] * * *} \\
(0.045)\end{array}$ & $\begin{array}{c}-0.750 * * * \\
{[-1.31]^{* * *}} \\
(0.047)\end{array}$ & $\begin{array}{c}-0.725 * * * \\
{[-1.25]^{* * *}} \\
(0.043)\end{array}$ \\
\hline $\begin{array}{l}\text { Hansen Chi }{ }^{2} \text { p-value } \\
\text { Observations } \\
\text { Countries } \\
\text { R-squared }\end{array}$ & $\begin{array}{c}240 \\
14 \\
0.002\end{array}$ & $\begin{array}{c}240 \\
14 \\
0.477 \\
\end{array}$ & $\begin{array}{c}\mathbf{0 . 5 5 3} \\
240 \\
14 \\
0.552\end{array}$ & $\begin{array}{c}\mathbf{0 . 8 3 9} \\
240 \\
14 \\
0.495\end{array}$ & $\begin{array}{c}\mathbf{0 . 1 3 9} \\
240 \\
14 \\
0.550\end{array}$ \\
\hline R-squared & \multicolumn{5}{|c|}{ Panel B: First stage results } \\
\hline Trade openness & & & $\begin{array}{c}0.373 * * * \\
(0.061)\end{array}$ & $\begin{array}{l}0.423 * * * \\
(0.059)\end{array}$ & $\begin{array}{l}0.366 * * * \\
(0.069)\end{array}$ \\
\hline Tariff rate & & & $\begin{array}{l}-0.977 * * \\
(0.427)\end{array}$ & & $\begin{array}{c}-0.914 * * \\
(0.425)\end{array}$ \\
\hline Agriculture share & & & & $\begin{array}{l}-0.139 \\
(0.109)\end{array}$ & $\begin{array}{l}-0.093 \\
(0.107)\end{array}$ \\
\hline Initial GDP per capita & & & $\begin{array}{c}0.360 * * * \\
(0.043)\end{array}$ & $\begin{array}{l}0.250^{*} \\
(0.129)\end{array}$ & $\begin{array}{l}0.253 * * \\
(0.127)\end{array}$ \\
\hline Observations & & & 240 & 240 & 240 \\
\hline $\begin{array}{l}\text { First stage F-stat (excl. } \\
\text { IV) }\end{array}$ & & & 26.7 & 27.1 & 18.1 \\
\hline First stage partial $\mathrm{R}^{2}$ & & & 0.194 & 0.175 & 0.197 \\
\hline First stage $\mathrm{R}^{2}$ & & & 0.517 & 0.506 & 0.512 \\
\hline
\end{tabular}

Notes: Private credit is instrumented using the followings: lagged trade volume as a fraction of GDP (IV1), lagged average tariff rate (IV2), and agriculture share in income (IV3). Robust standard errors are in parentheses. We use ***, **, and * to refer $1 \%, 5 \%$, and $10 \%$ significance level. For brevity, the constants are not reported for any of the regressions. The beta coefficients are reported in the squared brackets. They are obtained by transforming all the variables in the distribution with zero mean and unit standard deviation. 
Table 3 Full model of FD and Top 1\% Income shares

\begin{tabular}{|c|c|c|c|c|}
\hline \multirow[b]{2}{*}{ Dep. Var.=Top $1 \%$ income share } & (1) & (2) & (3) & (4) \\
\hline & \multicolumn{2}{|c|}{$O L S$} & \multicolumn{2}{|c|}{ IV regressions } \\
\hline \multirow[t]{3}{*}{ Private credit } & $0.151 * * *$ & $0.140 * * *$ & $0.700 * * *$ & $0.603 * * *$ \\
\hline & {$[0.23]^{* * *}$} & {$[0.22]^{* * *}$} & {$[1.08]^{* * *}$} & {$[0.96]^{* * *}$} \\
\hline & $(0.032)$ & $(0.034)$ & $(0.161)$ & $(0.163)$ \\
\hline \multirow[t]{2}{*}{ Initial GDP per capita } & $-0.239 * *$ & $-0.309 * * *$ & $-0.855 * * *$ & $-0.587 * * *$ \\
\hline & $\begin{array}{c}{[-0.41]^{* * *} *} \\
(0.093)\end{array}$ & $\begin{array}{c}{[-0.50]^{* * *} *} \\
(0.095)\end{array}$ & $\begin{array}{c}{[-1.48]^{* * *}} \\
(0.180)\end{array}$ & $\begin{array}{c}{[-0.95]^{* * *}} \\
(0.158)\end{array}$ \\
\hline \multirow[t]{2}{*}{ Investment } & 0.225 & $0.298 *$ & -0.154 & 0.007 \\
\hline & $(0.138)$ & $(0.157)$ & $(0.159)$ & $(0.164)$ \\
\hline \multirow{2}{*}{ Saving } & $-0.379 * * *$ & $-0.584 * * *$ & 0.05 & -0.209 \\
\hline & $(0.099)$ & $(0.105)$ & $(0.106)$ & $(0.137)$ \\
\hline \multirow[t]{2}{*}{$\mathrm{R} \& \mathrm{D}$ intensity } & $0.099 * * *$ & $0.136 * * *$ & $0.158 * *$ & $0.174 * *$ \\
\hline & $(0.029)$ & $(0.030)$ & $(0.066)$ & $(0.068)$ \\
\hline \multirow{2}{*}{ Years of education } & 0.098 & $0.335^{*}$ & -0.255 & $-0.926 * * *$ \\
\hline & $(0.115)$ & $(0.187)$ & $(0.162)$ & $(0.291)$ \\
\hline \multirow{2}{*}{$\begin{array}{l}\text { Fraction of population with Tertiary } \\
\text { education }\end{array}$} & 0.002 & -0.001 & $0.008 * * *$ & $0.008 * * *$ \\
\hline & $(0.002)$ & $(0.002)$ & $(0.002)$ & $(0.002)$ \\
\hline Government expenditure & $\begin{array}{c}-0.401 * * * \\
(0.065)\end{array}$ & $\begin{array}{c}-0.190 * * * \\
(0.069)\end{array}$ & $\begin{array}{c}-0.09 \\
(0.094)\end{array}$ & $\begin{array}{c}-0.246 * * * \\
(0.063)\end{array}$ \\
\hline Top marginal tax rate & & $\begin{array}{c}-0.270 * * * \\
(0.056)\end{array}$ & & $\begin{array}{c}0.075 \\
(0.085)\end{array}$ \\
\hline Hansen $\mathbf{J}$ statistics & & & 0.321 & 0.360 \\
\hline Observations & 186 & 134 & 186 & 134 \\
\hline R-squared & 0.648 & 0.684 & 0.66 & 0.788 \\
\hline \multicolumn{5}{|l|}{ First stage statistics } \\
\hline F-statistic & & & 8.02 & 6.27 \\
\hline Partial $\mathrm{R}^{2}$ & & & 0.132 & 0.133 \\
\hline $\mathrm{R}^{2}$ & & & 0.719 & 0.796 \\
\hline
\end{tabular}

Notes: lagged trade volume as a fraction of GDP (IV1), lagged average tariff rate (IV2), and agriculture share in income (IV3). Robust standard errors are in the parentheses. We use ***,**, and * to refer $1 \%, 5 \%$, and $10 \%$ significance level. The constants are not reported for any of the regressions. The beta coefficients are reported in the squared brackets. They are obtained by transforming all the variables in the distribution with zero mean and unit standard deviation. 
Table 4 Exclusion restriction test-full model

\begin{tabular}{lcccc}
\hline Dep. Var.=Top 1\% income shares & $(1)$ & $(2)$ & $(3)$ & $(4)$ \\
\hline Private credit & $0.648 * * *$ & $0.563 * * *$ & $0.683 * * *$ & $0.640 * * *$ \\
& $(0.153)$ & $(0.158)$ & $(0.166)$ & $(0.209)$ \\
Initial GDP per capita & $-0.831 * * *$ & $-0.602 * * *$ & $-0.840^{* * *}$ & $-0.617 * * *$ \\
& $(0.174)$ & $(0.150)$ & $(0.179)$ & $(0.183)$ \\
Trade openness & $\mathbf{0 . 0 9 5}$ & $\mathbf{0 . 0 9 7}$ & & \\
& $\mathbf{( 0 . 0 6 1 )}$ & $\mathbf{( 0 . 0 8 3 )}$ & & \\
Tariff rate & & & $\mathbf{- 0 . 0 0 8}$ & $\mathbf{0 . 0 0 8}$ \\
& & 0.073 & $\mathbf{( 0 . 0 1 7})$ & $\mathbf{( 0 . 0 2 4 )}$ \\
Top marginal tax rate (TMTR) & & $(0.082)$ & & 0.090 \\
& & & & $(0.098)$ \\
Observations & 186 & 134 & 186 & 134 \\
R-squared & 0.685 & 0.799 & 0.667 & 0.778 \\
Hansen J statistic & 0.990 & 0.360 & 0.185 & 0.188 \\
& & & & \\
First stage statistics & & & & \\
$\quad$ F-statistic & 11.9 & 8.52 & 11.5 & 5.68 \\
Partial R & & & & \\
$\mathrm{R}^{2}$ & 0.126 & 0.128 & 0.124 & 0.100 \\
\hline
\end{tabular}

Notes: Trade volume as a fraction of GDP and tariff rates are used as additional control variables in the full model. All the control variables are not reported to conserve space. The beta coefficients are reported in the squared brackets. They are obtained by transforming all the variables in the distribution with zero mean and unit standard deviation. Instruments used for FD are lagged trade volume as a fraction of GDP (IV1), lagged average tariff rate (IV2), and agriculture share in income (IV3). Robust standard errors are in the parentheses. We use $* * *, * *$, and $*$ to refer $1 \%, 5 \%$, and $10 \%$ significance level. 
Table 5 Robustness check using alternative measures of top income and financial development

\begin{tabular}{|c|c|c|c|c|c|c|c|}
\hline Dep. Var. $\rightarrow$ & $\begin{array}{c}(1) \\
\text { Top 10\% }\end{array}$ & $\begin{array}{c}(2) \\
\text { Top 5\% }\end{array}$ & $\begin{array}{c}(3) \\
\text { Top } 0.5 \%\end{array}$ & $\begin{array}{c}(4) \\
\text { Top } 0.1 \%\end{array}$ & $\begin{array}{c}(5) \\
\text { Top2- } \\
10 \%\end{array}$ & $\begin{array}{c}(6) \\
\text { Top 1\% }\end{array}$ & $\begin{array}{c}(7) \\
\text { Top 1\% }\end{array}$ \\
\hline & \multicolumn{7}{|c|}{ Panel A: Basic model } \\
\hline Private credit & $\begin{array}{c}0.237 * * * \\
{[0.92]^{*} * *} \\
(0.028)\end{array}$ & $\begin{array}{c}0.349 * * \\
\lceil 1.02\rceil^{* * *} \\
(0.049)\end{array}$ & $\begin{array}{c}0.719 * * * \\
\lceil 1.09\rceil^{* *} \\
(0.090)\end{array}$ & $\begin{array}{c}1.185 * * * \\
\lceil 1.31\rceil^{* * *} \\
(0.150)\end{array}$ & $\begin{array}{c}0.045^{*} \\
\lceil 0.25\rceil^{*} \\
(0.023)\end{array}$ & & \\
\hline Bank assets & & & & & & $\begin{array}{c}0.839 * * * \\
\left\lceil 1.371^{* *}\right. \\
(0.193)\end{array}$ & \\
\hline Broad monev & & & & & & & $\begin{array}{c}1.256 * * * \\
\lceil 1.53\rceil^{* * * *} \\
(0.351)\end{array}$ \\
\hline Observations & 181 & 222 & 188 & 206 & 183 & 240 & 240 \\
\hline R-squared & 0.610 & 0.539 & 0.564 & 0.384 & 0.213 & 0.182 & -0.115 \\
\hline Hansen $\mathbf{J}$ statistic & 0.971 & 0.324 & 0.047 & 0.443 & 0.435 & 0.308 & 0.071 \\
\hline First stage & & & & & & & \\
\hline F-stat & 20.4 & 18.5 & 17.8 & 18.5 & 19.9 & 7.87 & 4.80 \\
\hline Partial $\mathrm{R}^{2}$ & 0.260 & 0.191 & 0.230 & 0.207 & 0.253 & 0.136 & 0.066 \\
\hline $\mathrm{R}^{2}$ & 0.477 & 0.497 & 0.486 & 0.496 & 0.354 & 0.580 & 0.181 \\
\hline
\end{tabular}

\section{Panel B: Full model}

\begin{tabular}{cccccc} 
& & & \multicolumn{3}{c}{ Pancl } \\
\cline { 2 - 6 } Private credit & $0.248^{* * *}$ & $0.424 * *$ & $0.918^{* * *}$ & $1.318^{* * * *}$ & $0.117 * *$ \\
& $\lceil 0.84]^{* * *}$ & $\lceil 1.13]^{* *}$ & $\lceil 1.24]^{* * *}$ & $\lceil 1.31]^{* * *}$ & {$[0.58]^{* *}$} \\
& $(0.062)$ & $(0.077)$ & $(0.205)$ & $(0.282)$ & $(0.055)$
\end{tabular}

Bank assets

Broad money

$0.791 * * *$

$[1.25]^{* *}$

$(0.298)$

\begin{tabular}{|c|c|c|c|c|c|c|c|}
\hline \multicolumn{7}{|l|}{ Broad money } & \multirow{2}{*}{$\begin{array}{c}0.722 * * * \\
\lceil 0.791 * * * \\
(0.171) \\
186\end{array}$} \\
\hline Observations & 134 & 170 & 140 & 156 & 135 & 186 & \\
\hline R-squared & 0.767 & 0.66 & 0.628 & 0.569 & 0.382 & 0.404 & 0.591 \\
\hline Hansen J statistic & 0.458 & 0.143 & 0.121 & 0.294 & 0.008 & 0.153 & 0.861 \\
\hline \multicolumn{8}{|l|}{ First stage } \\
\hline F-stat & 7.00 & 8.54 & 7.60 & 8.56 & 8.31 & 3.95 & 7.50 \\
\hline Partial R ${ }^{2}$ & 0.110 & 0.143 & 0.143 & 0.146 & 0.125 & 0.058 & 0.136 \\
\hline $\mathrm{R}^{2}$ & 0.732 & 0.717 & 0.700 & 0.713 & 0.741 & 0.735 & 0.308 \\
\hline & \multicolumn{7}{|c|}{ Panel C: Full model including top marginal tax rate } \\
\hline Private credit & $\begin{array}{c}0.267 * * * \\
\lceil 0.971 * * * \\
(0.086)\end{array}$ & $\begin{array}{c}0.404 * * \\
\left\lceil 1.111^{*} *\right. \\
(0.098)\end{array}$ & $\begin{array}{c}0.735 * * * \\
\lceil 1.041 * * * \\
(0.248)\end{array}$ & $\begin{array}{c}0.999 * * * \\
\lceil 1.05\rceil^{*} * * \\
(0.269)\end{array}$ & $\begin{array}{l}0.141 * \\
\left\lceil 0.711^{*}\right. \\
(0.080)\end{array}$ & & \\
\hline Bank assets & & & & & & $\begin{array}{c}0.716^{* *} * \\
\left\lceil 1.111^{* *}\right. \\
(0.297)\end{array}$ & \\
\hline Broad money & & & & & & & $\begin{array}{c}0.426 * * * \\
\lceil 0.481 * * * \\
(0.119)\end{array}$ \\
\hline Top marginal tax & $\begin{array}{c}0.088 * * \\
(0.035)\end{array}$ & $\begin{array}{c}0.04 \\
(0.056)\end{array}$ & $\begin{array}{c}0.13 \\
(0.131)\end{array}$ & $\begin{array}{c}0.162 \\
(0.141)\end{array}$ & $\begin{array}{c}0.053 \\
(0.036)\end{array}$ & $\begin{array}{c}0.014 \\
(0.098)\end{array}$ & $\begin{array}{c}-0.128^{* *} * \\
(0.052)\end{array}$ \\
\hline Observations & 108 & 134 & 117 & 129 & 109 & 134 & 134 \\
\hline R-squared & 0.747 & 0.703 & 0.794 & 0.776 & 0.384 & 0.695 & 0.799 \\
\hline $\begin{array}{l}\text { Hansen J statistic } \\
\text { First stage }\end{array}$ & 0.998 & 0.070 & 0.103 & 0.230 & 0.191 & 0.069 & 0.006 \\
\hline F-stat & 4.34 & 6.30 & 4.10 & 6.40 & 5.10 & 2.05 & 5.6 \\
\hline Partial $\mathrm{R}^{2}$ & 0.105 & 0.133 & 0.120 & 0.140 & 0.116 & 0.069 & 0.127 \\
\hline $\mathrm{R}^{2}$ & 0.800 & 0.796 & 0.793 & 0.798 & 0.810 & 0.818 & 0.518 \\
\hline
\end{tabular}


Notes: Only financial development variables are reported in all the three panels for brevity. In Panel C, the top marginal tax rate is added as a control variable in the full model. Private credit is instrumented using lagged average tariff rate and lagged trade volume as a fraction of GDP . Robust standard errors are in the parentheses. We use $* * *, * *$, and $*$ to refer $1 \%, 5 \%$, and $10 \%$ significance level. For brevity, the constants are not reported for any of the regressions. The beta coefficients are reported in the squared brackets. They are obtained by transforming all the variables in the distribution with zero mean and unit standard deviation.

Table 6 LSDVC and GMM estimates

\begin{tabular}{|c|c|c|c|c|c|}
\hline \multirow[t]{5}{*}{ Den. Var.: } & \multirow{2}{*}{\multicolumn{3}{|c|}{ (1a) $\frac{(1 \mathrm{~b})}{\text { LSDV estimates }}$}} & \multirow{2}{*}{\multicolumn{2}{|c|}{$\frac{(2 a)}{\text { GMM estimates }}$}} \\
\hline & & & & & \\
\hline & Initiated by & Initiated by & Initiated by & System & Difference \\
\hline & $\mathrm{AH}$ & $\mathrm{AB}$ & $\mathrm{BB}$ & GMM & GMM \\
\hline & estimator & estimator & estimator & & \\
\hline \multirow{4}{*}{ Private credit } & \multicolumn{5}{|c|}{ Panel A: Without controlling for top marginal tax rates } \\
\hline & $0.12 * * *$ & $0.10 * * *$ & $0.08 * * *$ & $0.14 * * *$ & $0.17 * * *$ \\
\hline & {$[0.22]^{* * *}$} & {$[0.17]^{* * *}$} & {$[0.15]^{* * *}$} & {$[0.25]^{* * *}$} & {$[0.30]^{* * *}$} \\
\hline & $(0.036)$ & $(0.021)$ & $(0.019)$ & $(0.020)$ & $(0.023)$ \\
\hline \multirow{2}{*}{$\begin{array}{l}\text { Initial } \\
\text { GDP/capita }\end{array}$} & $-0.088^{*}$ & -0.021 & 0.006 & -0.043 & $-0.112 * *$ \\
\hline & $(0052)$ & $(0024)$ & $(0016)$ & $(0.034)$ & (0 052) \\
\hline \multirow{3}{*}{$\begin{array}{l}\text { Lagged Dep. } \\
\text { Var. }\end{array}$} & $0.83 * * *$ & $0.95 * * *$ & $1.04 * * *$ & $0.91 * * *$ & $0.84 * * *$ \\
\hline & & & & & \\
\hline & $(0.088)$ & $(0.044)$ & $(0.027)$ & $(0.055)$ & $(0.087)$ \\
\hline \multirow[t]{2}{*}{ Constant } & & & & 0.001 & 0.692 \\
\hline & & & & $(0.393)$ & $(0.646)$ \\
\hline Observations & 262 & 262 & 262 & 262 & 248 \\
\hline \multirow[t]{2}{*}{ Countries } & 14 & 14 & 14 & 14 & 14 \\
\hline & \multicolumn{5}{|c|}{ Panel B: Controlling for top marginal tax rates } \\
\hline \multirow[t]{3}{*}{ Private credit } & $0.12 * *$ & $0.08 * * *$ & $0.08^{* * *}$ & $0.11 * * *$ & $0.15^{* * *}$ \\
\hline & {$[0.20]^{* *}$} & {$[0.15]^{* * *}$} & {$[0.14] * * *$} & {$[0.20]^{* * *}$} & {$[0.26] * * *$} \\
\hline & $(0.048)$ & $(0.028)$ & $(0.028)$ & $(0.023)$ & $(0.040)$ \\
\hline \multirow[t]{2}{*}{ GDP per capita } & -0.085 & -0.02 & 0.005 & 0.002 & -0.016 \\
\hline & $(0.068)$ & $(0.040)$ & $(0.039)$ & $(0.029)$ & $(0.062)$ \\
\hline \multirow{2}{*}{$\begin{array}{l}\text { Top marginal } \\
\text { tax rate }\end{array}$} & -0.07 & $-0.07 * *$ & -0.05 & $-0.10 * * *$ & $-0.12 * * *$ \\
\hline & $(0.061)$ & $(0.032)$ & (0.038) & $(0.038)$ & $(0.034)$ \\
\hline \multirow{2}{*}{$\begin{array}{l}\text { Lagged Dep. } \\
\text { Var. }\end{array}$} & $0.773 * * *$ & $0.877 * * *$ & $0.972 * * *$ & $0.916 * * *$ & $0.926 * * *$ \\
\hline & $(0.102)$ & $(0.074)$ & $(0.086)$ & $(0.050)$ & $(0.079)$ \\
\hline Observations & 182 & 182 & 182 & 182 & 170 \\
\hline Countries & 11 & 11 & 11 & 11 & 11 \\
\hline
\end{tabular}

Note: All the variables are in logarithms. Column (1a), (1b) and (1c) report the least square dummy variable (LSDV) estimates, initiated by $\mathrm{AH}, \mathrm{AB}$, and $\mathrm{BB}$ estimators, and subsequently corrected using the approach suggested by Bruno (2005). The beta coefficients are in square brackets. They are obtained by transforming all the variables in the distribution with zero mean and unit standard deviation. 
Table 7 Error correction models' estimates

\begin{tabular}{|c|c|c|c|c|c|c|}
\hline & \multicolumn{2}{|c|}{$\begin{array}{l}\text { Mean group } \\
\text { (MG) }\end{array}$} & \multicolumn{2}{|c|}{$\begin{array}{l}\text { Pooled Mean Group } \\
\text { (PMG) }\end{array}$} & \multicolumn{2}{|c|}{$\begin{array}{l}\text { Dynamic Fixed Effect } \\
\text { (DFE) }\end{array}$} \\
\hline & (1a) & (1b) & (2a) & (2b) & (3a) & $(3 b)$ \\
\hline & LR & SR & LR & SR & LR & SR \\
\hline & \multicolumn{6}{|c|}{ Dep. Var.: Top $1 \%$ income shares } \\
\hline Private credit & $\begin{array}{c}0.262 \\
(0.638)\end{array}$ & & $\begin{array}{l}1.240 * * * \\
(0.258)\end{array}$ & & $\begin{array}{r}0.749 * * \\
(0.179)\end{array}$ & \\
\hline GDP per capita & $\begin{array}{l}-2.145 \\
(1.681)\end{array}$ & & $\begin{array}{c}-0.484 * * * \\
(0.074)\end{array}$ & & $\begin{array}{c}- \\
0.511 * * \\
(0.086)\end{array}$ & \\
\hline $\begin{array}{l}\text { Error correction } \\
\left(\emptyset_{i}\right)\end{array}$ & & $\begin{array}{c}-0.281 * * * \\
(0.101)\end{array}$ & & $\begin{array}{c}-0.132 * * * \\
(0.036)\end{array}$ & & $\begin{array}{c}-0.182 * * * \\
(0.045)\end{array}$ \\
\hline$\Delta$ Private credit & & $\begin{array}{l}-0.018 \\
(0.061)\end{array}$ & & $\begin{array}{l}-0.025 \\
(0.063)\end{array}$ & & $\begin{array}{l}-0.025 \\
(0.046)\end{array}$ \\
\hline$\Delta$ GDP per capita & & $\begin{array}{c}0.084 \\
(0.118)\end{array}$ & & $\begin{array}{c}0.072 \\
(0.123)\end{array}$ & & $\begin{array}{c}0.103 \\
(0.119)\end{array}$ \\
\hline Constant & & $\begin{array}{l}1.560^{* *} \\
(0.714)\end{array}$ & & $\begin{array}{c}0.178 * * * \\
(0.051)\end{array}$ & & $\begin{array}{l}0.680 * * \\
(0.303)\end{array}$ \\
\hline Observations & 262 & 262 & 262 & 262 & 248 & 248 \\
\hline
\end{tabular}

Note: All the variables are in logarithms. Im-Pesaran-Shin panel unit-root tests indicate that all the main variablesprivate credit, top $1 \%$ income shares, and GDP per capita are I(1). Non-zero, negative $\emptyset_{\mathrm{i}}$ confirms a long run relationship between private credit and top $1 \%$ income shares at $1 \%$ level of significance. Comparison among the estimators using the Hausman test suggests that DFE estimates are preferable. 


\section{Figures}

Figure 1 Log-log plot of Ppivate credit and external instruments
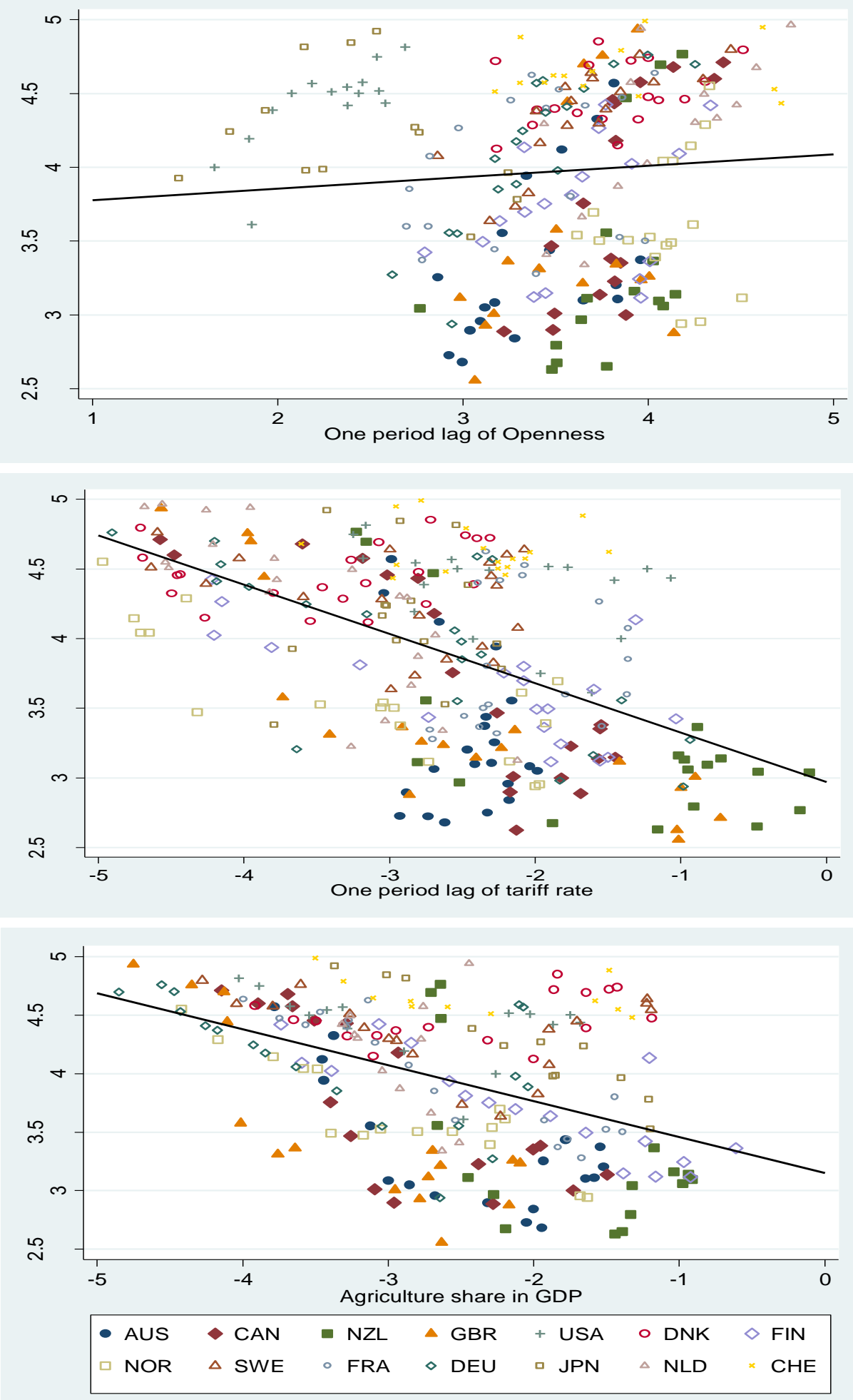
Figure 2. Non-Parametric local linear estimates
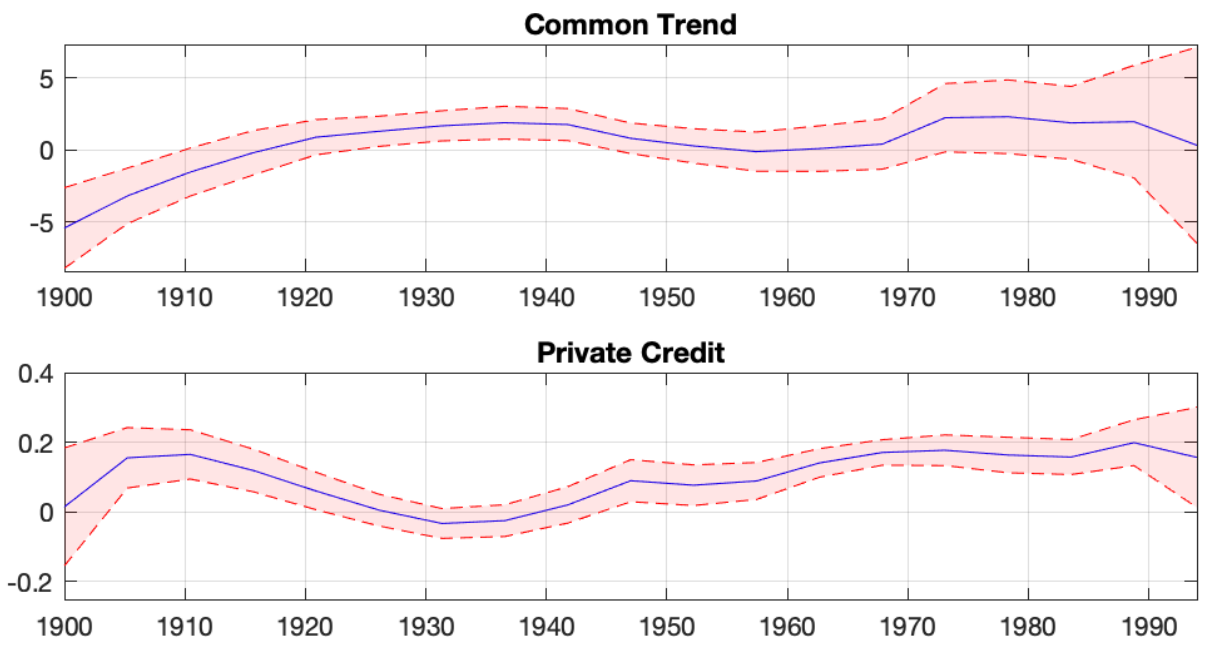

Initial GDP per Capita
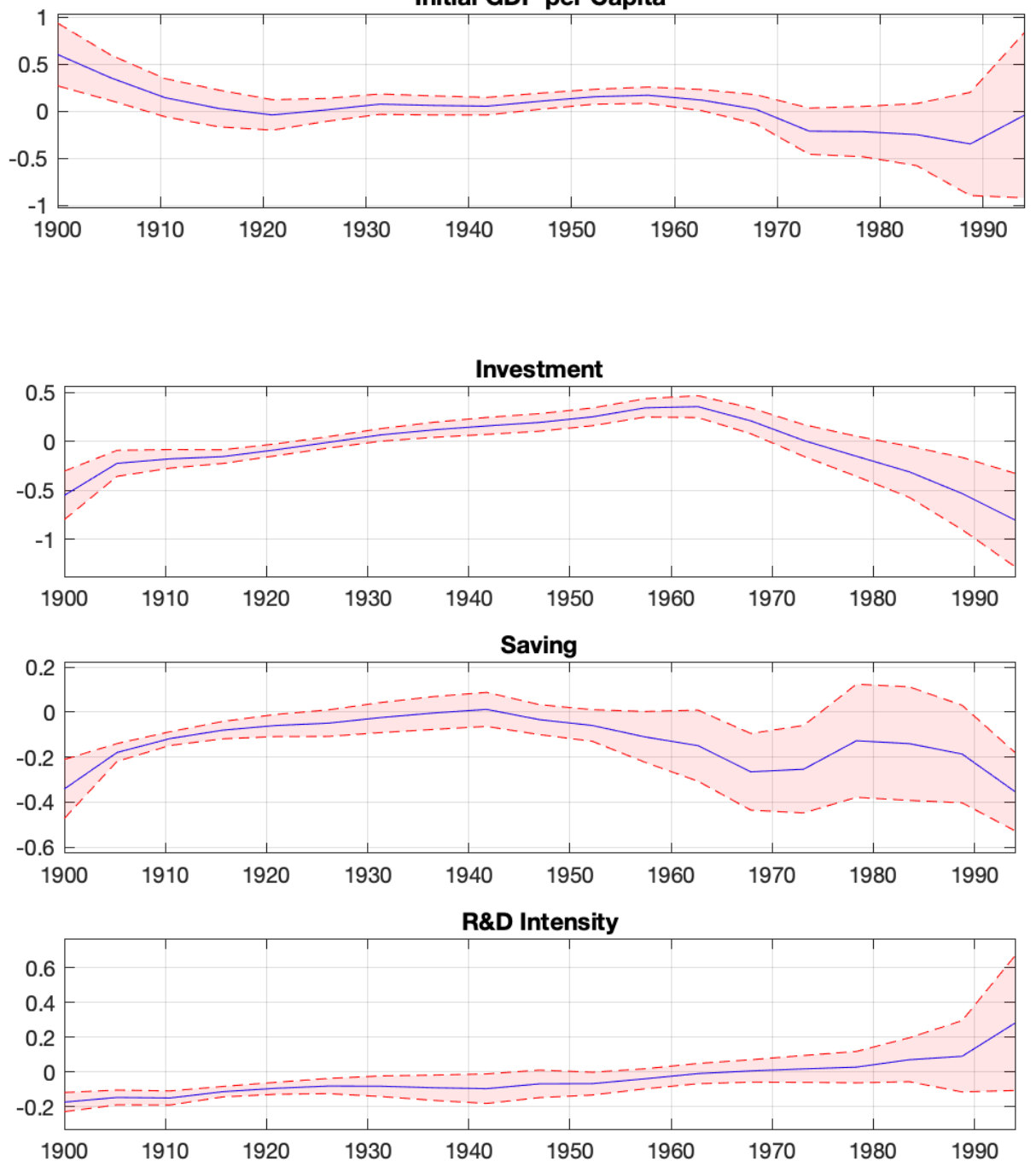


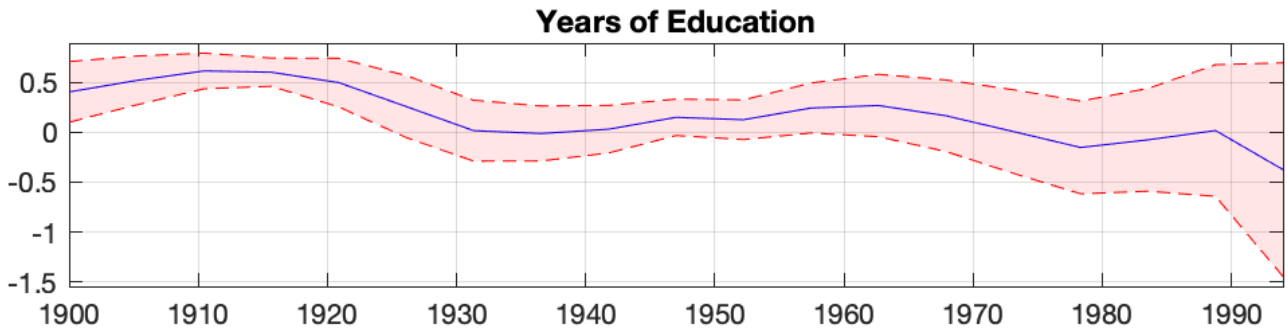

Fraction of population with Tertiary Education

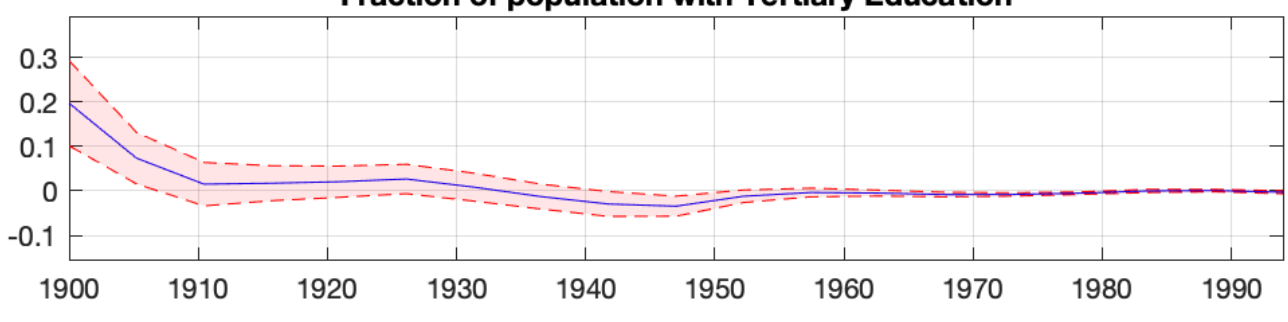

Government Expenditure

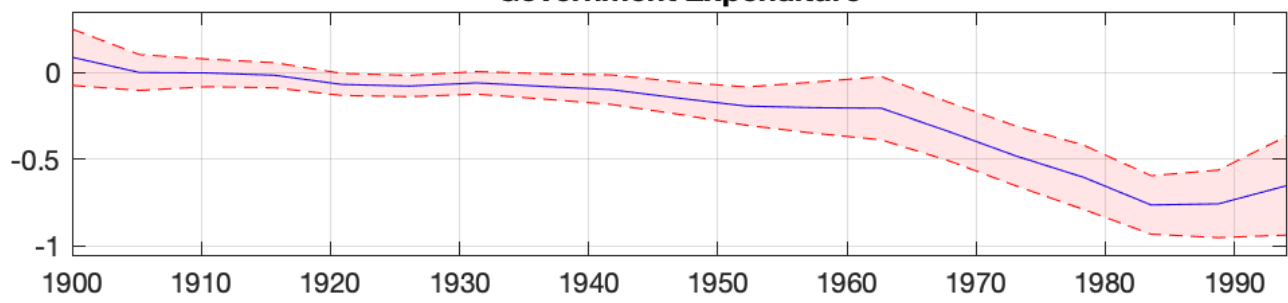


Online Appendix

Table A1 Summary of key variables

\begin{tabular}{lccccc}
\hline Variables & $\begin{array}{c}\text { Observatio } \\
\mathrm{n}\end{array}$ & Mean & St. dev. & Min & Max \\
\hline Private credit & 308 & 3.942 & 0.722 & 2.427 & 5.367 \\
GDP per capita & 308 & 8.905 & 0.730 & 7.072 & 10.260 \\
Trade openness & 253 & 3.527 & 0.727 & -0.876 & 5.903 \\
Investment & 462 & -2.244 & 0.239 & -3.572 & -1.715 \\
Broad money & 462 & -0.407 & 0.694 & -3.533 & 1.527 \\
Saving & 305 & -1.740 & 0.418 & -3.869 & -1.022 \\
Tariff rate & 294 & -2.821 & 1.281 & -11.243 & -0.118 \\
Agriculture share & 462 & -2.405 & 1.008 & -5.055 & -0.322 \\
R\&D intensity & 308 & -4.411 & 0.889 & -7.594 & -2.832 \\
Education years & 308 & 2.126 & 0.377 & -0.163 & 2.721 \\
Bank assets & 308 & 4.311 & 0.656 & 2.920 & 6.293 \\
Government & 279 & -2.133 & 0.607 & -4.506 & -0.876 \\
expenditure & & & & & \\
R\&D intensity & 308 & -4.410 & 0.889 & -7.593 & -2.831 \\
Top marginal tax rates & 196 & -0.858 & 0.637 & -3.689 & -0.025 \\
Top 10\% income & 216 & 3.532 & 0.179 & 3.095 & 4.099 \\
shares & & & & & \\
Top 5\% income shares & 266 & 3.157 & 0.236 & 2.572 & 3.720 \\
Top 1\% income shares & 288 & 2.310 & 0.407 & 1.348 & 3.285 \\
Top 0.5\% income & 225 & 1.971 & 0.472 & 0.801 & 3.019 \\
shares & & & & & \\
Top 0.1\% income & 247 & 1.150 & 0.634 & -0.572 & 2.589 \\
shares & & & & & \\
\hline Note: Variables are in natural logarithms & & & & \\
\end{tabular}

Table A2 Correlation among key variables

\begin{tabular}{llllllllll}
\hline & $(1)$ & $(2)$ & $(3)$ & $(4)$ & $(5)$ & $(6)$ & $(7)$ & (8) & (9) \\
\hline (1)Top1 & 1 & & & & & & & & \\
(2)GDP per capita & - & 1 & & & & & & & \\
& 0.60 & & & & & & & & \\
(3) Private credit & - & 0.50 & 1 & & & & & & \\
& 0.06 & & & & & & & & \\
(4)Tariff rate & 0.35 & - & -0.43 & 1 & & & & & \\
& & 0.55 & & & & & & \\
(5)Openness & - & 0.27 & 0.10 & - & 1 & & & & \\
& 0.16 & & & 0.48 & & & & & \\
(6)Educational & - & 0.77 & 0.36 & - & - & 1 & & & \\
attainment & 0.37 & & & 0.38 & 0.03 & & & & \\
(7) Bank assets & - & 0.58 & 0.74 & - & 0.35 & 0.36 & 1 & & \\
& 0.23 & & & 0.54 & & & & & \\
(8)Govt. expenditure & - & 0.72 & 0.21 & - & 0.21 & 0.48 & 0.38 & 1 & \\
& 0.68 & & & 0.51 & & & & & \\
(9) R\&D intensity & - & 0.56 & 0.21 & - & - & 0.40 & 0.28 & 0.57 & 1 \\
& 0.36 & & & 0.25 & 0.03 & & & & \\
\hline
\end{tabular}


Note: Variables are in natural logarithm 